\title{
問題解決を介した潜在構造の学習：
}

\author{
学習過程と認知的加齢の分析 \\ $\bigcirc$ 原田悦子 ${ }^{1,2} \cdot$ 山口一大 $(\text { 非会員 })^{1}$ ・須藤智 ${ }^{2,3}$ \\ $\left({ }^{1}\right.$ 筑波大学・ ${ }^{2}$ JST-RISTEX $・{ }^{3}$ 静岡大学) \\ キーワード : 問題解決による学習, 潜在構造, 認知的加齢
}

\begin{abstract}
Etsuko T. Harada ${ }^{1,2}$, Hirokazu Yamaguchi ${ }^{1}$ and Satoru Suto ${ }^{2,3, \#}$
$\left({ }^{1}\right.$ University of Tsukuba., ${ }^{2}$ JST-RISTEX, ${ }^{3}$ Shizuoka University)
\end{abstract}

Learning to solve a problem through finding a hidden structure: Changes on learning processes by cognitive aging.

Key Words: learning in problem solving, hidden structures, cognitive aging

社会の高齢化と情報化が同時にかつ急速に進む中，高齢者 にとっての使いやすさを明らかにし，誰にとっても使いやす い機器デザイン方法の解明が強く求められている (原田 2012). そこで本研究では, 人がモノを利用する際に必要とされる「人 工物を利用しながら，その表示・操作の背後にある潜在的な 構造を学習する」(Harada, Mori \& Taniue, 2010) 過程の加齢 による変動を，より統制された環境下で検討するため，実験 課題として Groton 迷路課題 (GMLT) を取上げた。「同じ迷路を 5 回解く」間にどのような学習が生ずるのか，そこに現れる 加齢の効果はどのようなものか，なぜそうした変化が生じる のかを検討するため, GMLT 学習指標の考案, 及び発話・行動 プロトコル分析による問題解決方略の分析を行った.

\section{方 法}

実験計画: 年齢群 $($ 若年/高齢) $\times$ 性 $($ 男/女) $\times$ 実験実施時間 $($ 午 前/午後 $) \times$ 試行回数 $(5$ : 参加者内要因) 94 要因混合計画。

実験参加者:若年成人 24 名 (大学生男女各 12 , 平均年齢 20.54 \pm 0.98 歳), 高齢者 24 名 (シルバー人材センターより派遣, 男女各 $12,69.46 \pm 2.73$ 歳)。

課題 : 問題解決型学習課題としてGMLT (CogState Research Inc. ) を利用。テストでは $10 \times 10$ のマスに隠された正解経路 (左上から右下まで)を一つずつ枡にタッチしながら探索する ことが求められた。タッチしたマスの正否はフィードバック され，不正解時には正しいルートに戻ってから再度正解経路 を探すよう求められた。

機材：タブレットPC (Panasonic $\mathrm{CF}-\mathrm{C} 1 \mathrm{~A})$, 画面ならびに発 話をビデオ録画した。

手続き：個別実験. 実験は認知機能の概日リズム変動から, 午前 $(9: 00 〜 11: 30)$ または午後 $(13: 30 〜 15: 00)$ に実施した。 実験の概要説明の後, 発話思考の説明・練習を行い, その後 GMLT の課題説明を行った. $6 \times 6$ マスでの練習試行 (3 試行) の 後, 本試行では同じ正解を持つ 5 試行が繰り返された。本試 行後に経路再生課題, Corsi Block 課題, o-span 課題, MMSE (高 齢者群のみ)を実施した。実験時間は大学生は 60 分、高齢者 は90 分程度であった。

\section{結 果}

GMLT のオリジナル指標の結果分析については別報する (須 藤・山口・小西・Lin・原田, 2012).

学習指標 : GMLT オリジナル指標はいずれも反応速度とエラー に基づいており「どれだけ学習がなされたか」についての直 接的な指標ではない，そこで迷路課題における学習は「正解 経路を連続して選択し，その系列が長くなること」と考え， 連続正答チャンク数 (2 以上の連続正解が得られた塊の数), 平均連続正答数 (各チャンクの連続正答数の平均 Consecutive Correct Responses : CCR)を算出した。 それぞれについて，4 要因 ANOVA を実施したところ，チャンク数については，年齢 の主効果 $\left(\mathrm{F}=12.37, \mathrm{p}=.001, \eta^{2}=.236\right)$, 試行の主効果

$(\mathrm{F}=14.54, \mathrm{p}<.001 ， \eta \hat{} 2=.267)$ ，ならびに両者の交互作用 $(\mathrm{F}=4.23, \mathrm{p}=.002, \eta 22=.095)$ を示し, 若年群は試行の効果が
有意（ $\mathrm{p}=.046 ）$ だが高齢群 では有意ではなかった $(\mathrm{p}=.11)$.また第 1 試行のみ 年齢群間で差がなかった。 性別，実施時刻はいずれも 試行数との交互作用のみ有 意傾向を示した.

平均連続正答数 (図 1) に ついては, 年齢の主効果 $\left(\mathrm{F}=11.21, \mathrm{p}=.002, \eta^{\wedge}{ }^{2}\right.$

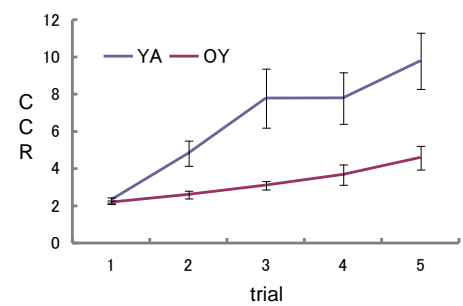

図 1 年齢群別 CCR (平均連続正答数) の試行に伴う変化 $=.219)$, 試行の主効果 $(\mathrm{F}=16.09, \mathrm{p}<.001, \eta \hat{2}=.287)$, ならびに両者の交互作用 $(\mathrm{F}=4.79, \mathrm{p}=.001, \eta \hat{} 2=.107)$ を示 し，特に第 1 試行では年齢間で連続正答数に差がないが，第 2 試行以後では年齢による差が見られた。性別，実施時刻に ついては主効果・交互作用ともに見られなかった.

方略の分析 : 試行中の発話・操作を書起し，代表的な 4 つの 方略の出現をカウントした : SSG (右下直進方略), 経路選択で 右・下が優先性を持ち, 同時に一つ前と同じ方向性を選ぼうと する（例：「とりあえず，まっすぐ行くか」）；NGS(右下非直線 方略)，右・下を優先するが，一つ前の選択とは異なる方向を とる方略; RS (想起方略), 以前の試行での正解経路を思い出 そうとする方略 (「確かこっちのほうだったと思う。」)；OCS (一対一対応方略), 一選択ごとに正解の意味を考え, 擬人的 反応をする方略 (「そう来るならこっちだ」). 各試行ごとの方 略出現率を図 2 に示す。 $\chi^{2}$ 検定の結果, 若年成人では第 1 試 行で SGS が多くその後で減少, 第 2 試行以後では RS が増加す ることが示された．高齢群では明確な試行間の方略変化が示 されなかった。

表 1 年齢群別の方略出現頻度

\begin{tabular}{crrrrrrrrrrr} 
O.A. & $\# 1$ & $\# 2$ & $\# 3$ & $\# 4$ & $\# 5$ & Y..A. & $\# 1$ & $\# 2$ & $\# 3$ & $\# 4$ & $\# 5$ \\
\hline SGS & 11 & 9 & 7 & 4 & 3 & SGS & 17 & 12 & 4 & 4 & 5 \\
NGS & 16 & 12 & 12 & 10 & 10 & NGS & 14 & 2 & 3 & 3 & 1 \\
RS & 1 & 19 & 20 & 21 & 20 & RS & 0 & 23 & 23 & 23 & 23 \\
OCS & 7 & 8 & 6 & 9 & 6 & OCS & 3 & 5 & 2 & 3 & 1 \\
\hline
\end{tabular}

分析の結果，チャンクごとの平均連続正答数において，学 習の様子が表現可能であり，若年成人と高齢者では学習のあ り方が異なることが示された．その原因として，若年群は明 瞭な方略を示すことが多く，また意図的に過去の試行を想起 していることが示された。一方，操作分析の結果から高齢者 群で「エラーを含めて」全く同じ経路選択をする場合が見ら れ，自動的な記憶検索と意図的な記憶想起利用が年齢群によ って異なる可能性が示され，今後さらなる分析が必要と考え られる。

引用文献:須藤・山口・小西・Lin・原田 2012 問題解決型学習過程に対 する年齢差・性差・概日リズムの影響 日本認知心理学会第 10 回大会. 